\title{
THE COMMONWEALTH OF INDEPENDENT STATES: DECAYED WITHIN A DECADE
}

KEMAL BAŞLAR

\begin{abstract}
:
The Commonwealth of Independent States (CIS) is an international organisation comprised of 12 sovereign states of former-Soviet Union. The genesis of the CIS dates back to 8 December 1991, thus 2001 heralded the tenth anniversary of this sui generis organisation. Although a decade elapsed, one would tentatively argue that the CIS is far from being a solidified structure whereby to further the interests of member states. To depict the loopholes within this structure, this paper is constructed on three layers: First, to introduce the reader the basic structure of the CIS. Secondly, to assess the legal status of the CIS and to answer to what extent the CIS has acquired a firm basis in international law and finally to draw lessons from the institutional mistakes made in the advancement a new regional organisation. Portraying this is important inasmuch as the failure of this integration model might prevent similar mistakes from being repeated in the sub-regional integration models.
\end{abstract}

\section{KEYWORDS:}

The Commonwealth of Independent States; International Legal Status of the CIS; Legal Integration of Ex-Soviet States; The Eurasian Economic Community; Regional Organisations. 


\section{1- Introduction}

The Commonwealth of Independent States (hereinafter the CIS, in Russian as Sodruzhestvo Nezavisimykh Gosudarstv) is a free association of sovereign states which was formed with an agreement in 8 December 1991. ${ }^{1}$ This organisation comprises Russia and 11 other republics that were formerly part of the Soviet Union. On 8 December 1991 the elected leaders of Russia, Ukraine and Belarus signed an agreement forming a new association to replace the crumbling Union of Soviet Socialist Republics (U.S.S.R.). The three Slavic republics were subsequently joined by the Central Asian republics of Kazakhstan, Kyrgyzstan, Tajikistan, Turkmenistan, Uzbekistan, by the Transcaucasian republics of Azerbaijan, Armenia and Georgia, and by Moldavia, while the remaining former Soviet republics of Lithuania, Latvia and Estonia declined to join the new organisation. The Commonwealth officially came into being on 21 December 1991, and its administrative centre is now situated in Minsk, Belarus. ${ }^{2}$

The year 2001 has a commemorative significance with regard to discussing the CIS in that 2001 marks the tenth anniversary of the official inauguration of the new organisation. Since then, sufficient time has elapsed to permit us to draw certain conclusions concerning the past, present and future of the CIS. In so doing, unlike earlier writers I am rather fortunate as I have had the chance to cast light on the CIS from the vantage points of a decade-lasting experience. ${ }^{3}$ In addition, May 2001 heralded the birth of a new community within the CIS mould: The Eurasian

\footnotetext{
${ }^{1}$ Reprinted both in United Nations General Assembly Offical Records, $46^{\text {th }}$ Session, p. 2, UN Doc. A/46/771 (1991); and in International Legal Materials (ILM), Vol. 31, 1992, p. 148.

${ }^{2}$ For further information see K. Mihalisko, 'Year in Review 1998: WorldAffairs' at [http://www.britannica.com/seo/c/commonwealth-of-independentstates: Commonwealth of Independent States, United States. Central Intelligence Agency, Washington, D.C., 2000], 14 March 2001.

${ }^{3}$ For example Sergei Voitovich sees himself as handicapped as he had to base his research merely on the texts of the CIS basic constituent instruments, some available factual data and initial, mostly non-legal, comments: S. A. Voitovich, 'The Commonwealth of Independent States: An Emerging Institutional Model', European Journal of International Law, Vol. 4 (3), 1993, p. 418.
} 
Economic Community (EEC). To what degree the "EEC II", so to speak, will be akin to its predecessor is hinged on how better the CIS integration is perceived. It is therefore very pertinent and timely to assess the past and the mistakes of the CIS to portend if there is any chance of its resuscitation.

To this end, the aim of this study is threefold: First, to introduce the reader the basic structure of the CIS. Secondly, to assess the legal status of the CIS and to answer to what extent the CIS has acquired a firm basis in international law and finally to draw lessons from the institutional mistakes made in the advancement a new regional organisation. Portraying this is important inasmuch as the failure of this integration model might prevent similar mistakes from being repeated in the sub-regional integration models.

Even though this paper aims to assess whether the CIS is an example of successful integration and could be a model for the future, in the interim however, a common statement, seen in many documents touching on the political, economic, military and legal aspects of the CIS, is frequently encountered. ${ }^{4}$ According to which, the CIS, ever since its inception, failed to be a successful model of integration. The future of the CIS appears to be bleak. One ventures to say that the CIS is a sick-man waiting for his end.

\footnotetext{
${ }^{4}$ For in-depth analyses of the CIS, see, (British) Foreign and Commonwealth Office, The Commonnwealth of Independent States: International Status (no. 258), September 1994 (unpublished paper, available at the British Library and National Library of Wales); T. W. Murphy, 'The Commonwealth of Independent States as a Legal Phenomenon', Journal of Legal Studies, Vol. 5, 1994, p. 57; A. G. Khodakov, 'The Commonwealth of Independent States: Realities and Prospects', Emory International Law Review, Vol. 7 (1), 1993; I. P. Blishchenko, 'International Law Problems of the CIS Member States', Moscow Journal of International Law, Vol. 1, 1997, pp. 2-9; S. Kux, 'Confederalism and Stability in the Commonwealth of Independent States', New Europe Law Review, Vol. 1 (2), 1993, p. 387; G. M. Danilenko, 'The Confederate Model of the Commonwealth of Independent States: The New Russian Federalism', New Europe Law Review Vol. 1 (2), 1993, p. 367; G. D. Jackson, 'Russia and the Commonwealth of Independent States', Journal of International Law and Practice, Vol. 2 (1), 1993, p. 173; P. Vratislav, 'The Commonwealth of Independent States: A Legal Profile', The Parker School Journal of East European Law, Vol. 2 (4-5), 1995, p. 583.
} 
Therefore, this paper will look at legal weaknesses inherent in the CIS ever since its advent so that similar symptoms be ameliorated in other organisations facing the same problems.

Seen in this way, the CIS is an excellent example to study how such an organisation could be established so weak as to crumble into pieces within a couple of years. ${ }^{5}$ Admittedly, the leaders, remnants of the former USSR, with no liberal and democratic pedigree could not do better than this. Or rather, let us put the problem euphemistically: The reason why the CIS has failed to integrate the Soviet successor states in any meaningful sense was that it is an example of, "organisational cloning", or in other words an institutional "dolly". In the eyes of Russians, after the collapse of the USSR, the most rational thing was to extract the DNA, that is to say, the spirit of the old Empire, namely the Russian hegemony, and transplant in vitro into the cell of the CIS. In the process of in vitro fertilisation, the genetic code of the European Union were used. All the same, the outcome was the failure of Russian social engineers. The transplantation was doomed to fail. After all, what was conjured up was not a rejuvenated Russian bear, but only a teddy bear.

Nevertheless, the failure of the CIS encapsulates important lessons in its short span of life. Studying over them will garner many lessons for the future. ${ }^{6}$ However, within the ambit of this paper, only three façades of the problem will be relayed. (1) Institutional Problem: That is, the international legal status of the

5 Among others see, D. Kalipada, Soviet Union to Commonwealth: Transformation and Challenges, New Delhi, M. D. Publications, 1996.

${ }^{6}$ For example Lewis Young wrote an article to show that the political future and stability of the Central Asian republics is a key to South West Asian nations' security. Hence, he argued that the political development and future alliances will have an impact on the regional balance of power among nations more distant from these former Soviet republics, see L. Young, infra, 'Living in a Multi-Polar World': Has the Commonwealh of Independent States Already Disintegrated?', Asian Defence Journal, 1992; A. Ewart, 'The Commonwealth of Independent States: Political and Economic Integration Among the States of the Former Soviet Union', The Parker School Journal of East European Law, Vol. 5 (4), 1998, p. 373. See also J. Weiler, 'Economic Integration in the Commonwealth of Independent States', The Parker School Journal of East European Law Vol. 4 (1), 1997, p. 107. 
CIS has never been crystal clear. This deficiency has devoid the CIS of its legal personality. (2) Decision-making system: The CIS established so weak a decision-making system that it is no wonder that the targets of the CIS as laid down in constitutive instruments have never been met. (3) Lack of normative supranationality: In other words, the CIS founders appears to have ignored or, at least, underscored the fact that a successful integration such as the European one could only be an outcome of an intricate amalgamation of politics, economics and law. ${ }^{7}$ Although the decision to set up the CIS was a political act overwhelmingly motivated by economic and security reasons, but unlike the European integration, the law was not used as the agent of cohesion. Therefore, even though the Slavic and Central Asian integration process has expanded remarkably ever since 1991, as the legal instruments were not used effectively, the CIS is all but about to collapse. Therefore, in the third section of the paper, a comparison will be made with the European integration model to verify this axiom.

\section{2- Brief Overview of the Organisation: The CIS with Hindsight}

On 8 December 1991 in Minsk the leaders of the three Slav Republics of the Soviet Union hastily penned and signed both the Declaration by the Heads of State of the Republic of Belarus, the Russian Soviet Federative Socialist Republic and Ukraine, and the Agreement Establishing the Commonwealth of Independent States. The Alma-Ata summit of 21 December 1991, was another crucial leap in the speedy transition from the USSR to the CIS. The leaders of eleven Member States of the Soviet Union, apart from Georgia, confirmed and developed the Minsk arrangements. All States signed and ratified the Protocol to the Agreement Establishing the CIS, which at the same time terminated the USSR. ${ }^{8}$

\footnotetext{
${ }^{7}$ Cf. F. Snyder, New Directions in European Community Law, London, Weidenfeld and Nicolson, 1990, p. 5.

${ }^{8}$ See for the official texts, Commonwealth of Independent States Documents, adopted by the Heads of State and Government, 8 December 1991-30 April 1992, Washington, D.C.: Foreign Broadcast Information Service, 1992.
} 
As far as Article 1 of the 1993 Charter of the Commonwealth of Independent States, the CIS is based on principles of sovereign equality of all its members which are independent subjects of international law having equal rights. The CIS Charter lays down a multi-purpose regional organisation with rather close cooperation in terms of political, military, economic, social and cultural spheres. ${ }^{9}$

The Commonwealth was devised to serve for the further development and strengthening of the relationships of friendship, good neighbourhood, inter-ethnic harmony, trust, mutual understanding and mutually advantageous cooperation among the member states. The objectives of the Commonwealth was articulated in Article 2 of the Charter;

i. cooperation in political, economic, ecological, humanitarian, cultural and other fields;

ii. comprehensive and well-balanced economic and social development of the Member States within the framework of a common economic space, interstate cooperation and integration;

iii. ensuring human rights and fundamental freedoms in accordance with the universally recognized principles and norms of international law and the documents of the CSCE;

iv. cooperation among the Member States in safeguarding international peace and security;

v. implementing effective measures for the reduction of armaments and military expenditures, for the elimination of nuclear and other kinds of weapons of mass destruction, and for the achievement of universal and complete disarmament;

vi. promoting free communication, contacts and movement within the Commonwealth for the citizens of the Member States;

vii. mutual judicial assistance and cooperation in other spheres of legal relationships;

viii. peaceful settlement of disputes and conflicts among the States of the Commonwealth.

${ }^{9}$ G. M. Danilenko, 'Implementation of International Law in CIS States: Theory and Practice', European Journal of International Law, Vol. 10 (1), 1999, p. 66. 
Article 3 announces that the CIS members shall respect the universally recognized norms and principles of international law. The CIS is an open organisation; according to Article $7 /(3)$ of the Charter, states sharing the objectives and principles of the Commonwealth and accepting the obligations under the present Charter may accede with the consent of all member states.

As to the organs of the CIS; there are some 30 inter-state intergovernmental organs. The most important of which are the following:

(1) The Charter-based Organs: The supreme body of the Commonwealth is the Council of Heads of State (CHS) which discusses and solves any principle questions of the Commonwealth connected with the common interests of the participant states (Art. 21). The Council of Heads of Government (CHG) coordinates cooperation of the executive authorities of the participant states in economic, social and other spheres of their common interests (Art. 22). Decisions of the CHS and the CHG are adopted by consensus. This means that any member state may acknowledge about its lack of interest in one or another question, the fact being not considered as an obstacle for adopting a decision.

The Council of Ministers of Foreign Affairs is the main executive body ensuring cooperation in the field of foreign policy activities of the participant states of the CIS on the matters of mutual interest, adopting decisions during the period between the meetings of the CHS, the CHG and by their orders (Art. 27).

The Economic Court functions with the aim of ensuring the meeting of economic commitments in the framework of the CIS (Art. 32). Its terms of reference include settlement of interstate economic controversy arising in meeting economic commitments envisaged by Agreements and decisions of the CHS and the CHG of the CIS.

There are other Charter-based organs, namely the Coordinating-Consultative Committee (Art. 28), the Council of Ministers of Defence (Art. 30), the High Command of the United Armed Forces (Art. 30), the Council of Commanders of Border Troops (Art. 31), and the Commission on Human Rights (Art. 33). 
(2) There are other organs, set up at different dates; The Council of Collective Security is a supreme political body of the states participating in the Agreement on Collective Security of 15 May 1992, which provides for coordination and joint activities of the participant states with the aim of implementation of this Agreement. The Interstate Bank, set up under a special Agreement signed at the Minsk summit of 22 January 1993 by all ten participating States, is organization and implementation of multilateral interstate settlements between central (national) banks in relation to trade and other transactions, as well as coordination of monetary policy of the participant states.

The Interstate Statistical Committee (Statcommittee) was established in accordance with the decision of the Heads of Governments in December 1991 for coordinating activities of statistical organisations of the CIS countries, developing and implementing an unified statistical methodology on the basis of mutual consultations, securing comparability and continuity of statistical elaboration and alike. The Committee is entrusted with creating and maintaining common statistical database.

The CIS also created an Inter-State Free Trade Association; a Customs Union involving the reduction of tariffs on intra-CIS trade and the introduction of a common external tariff; the coordination of fiscal, currency and financial relations by means of a Payments Union of national currencies and multilateral clearance through an Inter-State Bank and an eventual transition to a Monetary Union.

In October 1992, an Agreement on a Common Monetary System and a Coordinated Monetary-Credit and Currency Policy of States Retaining the Ruble as Legal Tender was signed by eight states. Another Agreement on the Interstate Bank of the CIS was then prepared. In September 1993 the Heads of the CIS States signed an Agreement on the creation of Economic Union (the Treaty on Economic Union) to form the first stage in the establishment of a genuinely comprehensive common market through common economic space grounded on free movement of goods, services, labour force, capital; to elaborate coordinated monetary, tax, price, customs, external economic policy; to bring together methods of regulating economic activity and create 
favourable conditions for the development of direct production relations. ${ }^{10}$

In April 1994, a declaration was drafted to create a free-trade zone. In June 1994, Kazakstan's president, Nursultan Nazarbaev, an ardent pioneer of the integration, proposed the creation of a truly federal Eurasian Union based on principles of equality among states. ${ }^{11}$ In September 1994, Russia attempted to introduce an Interstate Economic Committee (IEC) that would create a tariff-free common trade zone within the CIS; member states of the IEC would coordinate their foreign trade and economic development policies. The committee, which would be the first functioning sitting body of the CIS, would be charged with a number of executive and managerial tasks, in exchange for which member states would give up certain national prerogatives. In October 1994, members officially created the Inter-State Economic Committee, announced as the first truly supranational CIS organ and presented as akin to the European Commission.

The CIS Coordinating Consultative Committee, which formulated the proposal, set, as one of the IEC's first tasks the creation of an intra-Commonwealth payments union, to serve as a clearing house for inter-republic debts. Over time this clearing house would evolve into a monetary union. Voting in the IEC is to be weighted in accordance with the amount of financing contributed by each state, with Russia putting in (and hence voting) 50 percent; major decisions, however, will require 75 percent of member votes. ${ }^{12}$

The Interparliamentary Assembly was established in March 1995 by the leaders of Supreme Soviet (parliaments) of the Commonwealth countries as a consultative institution to discuss

${ }^{10}$ E. Pain, 'The Russian Question From Internationalism to Nomenklatura Nationalism?', Russian Social Science Review, Vol. 41 (6), 2000, p. 48.

${ }^{11}$ This idea was widely rejected. President Islam Karimov of Uzbekistan called it "populist" and "not well thought out" while an official Uzbek paper claimed it was nothing more than "sheer gibberish", in P. Kubicek, 'End of the Line for the Commonwealth of Independent States', Problems of Post-Communism, Vol. 46 (2), 1999, p. 15.

12 M. B. Olcott, 'Sovereignty and the Near Abroad', Orbis, Vol. 39 (3), 1995 , p. 353. 
problems of parliamentary cooperation and develop proposals by the parliaments of the CIS states (Art. 37). In order to facilitate further integration, the Agreement on deepening of integration in economic and humanitarian field of four countries (Belarus, Kazakhstan, Kyrgyzstan, Russia) and Agreement on creation of Commonwealth of Sovereign Republics (Belarus and Russia) were signed in 1995.

In 1996, Nazarbaev drafted another program, "Integration 2000", but fell on deaf ears. ${ }^{13}$ By 1996, a customs union among Russia, Belarus, Kazakhstan, and Kyrgyzstan had been formally declared, but agreements on forming a common tariff structure were only signed in January 1998. Nazarbaev's proposal to turn this "group of four" into a common, CIS-wide economic space along the lines of the European Union was rebuffed by both Yeltsin and Lukashenko. ${ }^{14}$ In February 1999, by the decision of the Interstate Council of four countries (Belarus, Kazakhstan, Kyrgyzstan, Russia), Tajikistan was recognized as participant of the customs union enjoying full rights. ${ }^{15}$ Interaction of countries in the framework of the Commonwealth is realised through its coordinating institutions.

On 10 October 2000, the Custom Union was transformed into the Eurasian Economic Community (EEC) through a treaty signed by the abovementioned five independent states. This agreement entered into force, upon the signature of the said states, after 1 April 2001. The first official meeting of the Eurasian Economic Community (EEC) took place on 31 May 2001. Russia possesses 40 per cent vote in the EEC, Belarus and Kazakhstan enjoys 20 per cent and finally Tajikistan and Kyrgyzstan shares equally the rest 20 per cent.

Having seen the rudimentary structure of the organisation in a descriptive fashion, let us have a look at the problematic aspects of the Integration.

\footnotetext{
${ }^{13}$ Kubicek, End of the Line, p. 15.

${ }^{14}$ Ibid.

${ }^{15}$ For the past of the customs union see C. Michalopoulos, "The Economics of Customs Unions in the Commonwealth of Independent States', PostSoviet Geography and Economics, Vol. 38 (3), March 1997, p. 125.
} 


\section{3- The CIS's Uncertain International Legal Status}

The first problem to be dealt with is the international legal status of the CIS. If any traditional organisational model were to be applied, neither system would resemble this kind of entity that most politicians and jurists have in mind. The CIS is neither a state nor a super state, ${ }^{16}$ nor a quasi-state, or supranational organisation. Because, Article 1 of the CIS Charter says that " $[t] h e$ Commonwealth shall not be a state, nor possess supranational powers". If it had been a state, it would have become the successor state to the USSR. ${ }^{17}$ Needless to say, nor is there a Commonwealth citizenship, no standing joint armed forces and no common currency. 18

It goes without saying, it is not a federal state either since the CIS Charter cannot be construed as a federal constitution. In fact, federalism could not have been uttered at the birth of the CIS when the old satellite states had recently got rid of the shackles of the USSR. As a matter of fact, as shall be touched upon below, neither is it a confederation model in classical sense. One would admit that at best it is a sui generis structure which cannot be compared easily with existing political entities. Below are the arguments verifying why exact analogies with the existing state formations or interstate unions cannot be made.

Traditionally speaking, the CIS meets all the fundamental formal criteria of an intergovernmental organization, which are: (1) establishment on the basis of an international agreement in

${ }^{16} \mathrm{It}$ is not a state since it does not have a government, parliament, constitution and any enforcement mechanism to implement its decisions. CIS members agreed that Russia, Ukraine and Belarus would retain their memberships in the UN General Assembly. Russia assumed the Soviet seat on the UN Security Council. The CIS members accepted debt and treaty obligations of the CIS.

${ }^{17}$ H. Beemelmans, 'State Succession in International Law: Remarks on Recent Theory and State Practice', Boston University International Law Journal, Vol. 15, 1997, p. 71.

${ }^{18}$ R. Sakwa \& M. Webber, "The Commonwealth of Independent States, 1991-1998: Stagnation and Survival', Europe-Asia Studies, Vol. 51 (3), 1999 , p. 379. 
conformity with international law; ${ }^{19}$ (2) membership of sovereign states; (3) permanently functioning administrative structure; (4) at least an organ with a will of its own, established under international law; (5) the objective of coordination of the member states' cooperation in particular fields. ${ }^{20}$

Once agreed that it is an international organisation of some sort, the following questions should be asked: Does it have legal personality? Is it a regional organisation? Is it a confederation? If not, is it similar to the Commonwealth (formerly the [British] Commonwealth of Nations)? Or is it more akin to the International Organisation of La Francophonie? Or should it have been modelled on loose structures similar to the OSCE or the Council of Europe? To what extent has it similarities to NATO? Or is it an economic integration similar to EU? These are the questions that need to be handled.

\section{- The CIS has not been conferred on international personality}

The fact that international organisations (IGOs) have been vested in international personality, albeit in a constraint sense, does not entail that all international organisations do possess legal personality of some sort. Generally speaking, organisations set up by treaties are devolved upon limited legal personality with which they can make treaties within the ambit of their aims, or exercise their functions and fulfil their purposes. Treaties establishing international organisations often provide clauses whether it is conferred on legal personality. ${ }^{21}$ As international organisations do

${ }^{19}$ The 1993 Charter is an international agreement or a treaty in the sense of the 1969 Vienna Convention on the Law of Treaties.

${ }^{20}$ Voitovich, An Emerging Institutional Model, p. 418. H. Schermers and N. Blokker, International Institutional Law, p. 3.

${ }^{21}$ For example Article 104 of the UN Charter provides that "the organisation shall enjoy in the territory of each of its members such legal capacity as may be necessary for the exercise of its functions and the fulfilment of its purposes'. Article 43 of the Charter empowers the UN to include certain types of treaty with member states". Article 210 of the Rome Treaty (after amendment Art. 281) says that the EC shall have legal personality. So does it say for the European Central Bank Statute (Article 9), and the 
not possess personality ipso facto and $a b$ initio, one should look at the attitudes of other states to elicit if the CIS is looked upon as a legal person. When heeded to the CIS Charter to find out whether or not the CIS has been vested in personality, one bumps into Article 1 of the 1993 Charter, which denounces that the CIS is a state and possess supranational authority. The Charter does not furnish explicit provisions on the treaty-making competence of the Commonwealth. This insinuates that the intention of Russia as well as those of 11 members states was to establish a low profile structure akin to OSCE. For example, Ukraine pursued a policy aimed at keeping the Commonwealth a weak confederation by rejecting attempts to set up permanent CIS coordinating structures and blocking efforts to build central CIS bureaucracy. ${ }^{22}$ The Central Asia leaders, too, were only demanding that Moscow recreate "an informal grouping" of former Soviet republics.

\section{- The CIS is not a regional organisation}

The term "regional organisation" has special meaning in the parlance of the United Nations. Geographically speaking, the CIS appears to be a regional organisation such as the EU or OSCE or NAFTA. As far as the UN Charter is concerned, articles enunciated in Chapter VIII (namely Article 52-54) regulate regional arrangements according to which these organisations could make every effort to achieve pacific or peaceful settlement of regional disputes. The Security Council is entitled to utilise them for enforcement action. They are authorised enforcement action with the consent of the Security Council and the Council will be fully informed of activities undertaken for the maintenance of international peace and security

European Monetary Institute (Article 109f), European Investment Bank (Article 198d). Note however that EC and EU are distinct concepts. This does not mean that EU unquestionably possess legal personality, see for this J.W. de Zwaan, 'The Legal Personality of the EC and the EU', Netherlands Yearbook of International Law, Vol. 30, 1999, pp. 75-114.

${ }^{22}$ K. Butterworth, 'Successor States- Property Rights- Russia and Ukraine Agree to Share Control of the Former Soviet Union's Black Sea Fleet', Georgia Journal of International and Comparative Law, Vol. 22 (3), 1992, fn. 33, p. 667. 
In December 1993, the CIS Heads of Government instructed the Chairman of the CIS Council of Foreign Ministers to ask the United Nations to grant the CIS observer status in the General Assembly. A draft resolution was adopted on 24 March 1994 without a vote. The Resolution was agreed upon the argument that the CIS Charter of 22 January 1993 furnished the legal framework of the organisation and the CIS had a standing executive body and more than 30 primary and subsidiary bodies. It was also argued that apart from economic dimension, it had also foreign policy and human rights dimensions. Therefore, Russia argued that the CIS was a regional organisation within the ambit of Chapter VIII of the UN Charter. ${ }^{23}$ However, the Ukrainian Ambassador to the UN rejected that the CIS was a subject of international law and claimed that it was a merely special international, inter-regional formation. The Ukraine advanced the argument that the CIS's observer status could only represent the member states which signed and ratified the Charter, which Ukraine did not. Conferring upon observer status, as far as Ukraine is concerned, should not be read as entailing that the CIS is a regional arrangement within the framework of Chapter VIII of the Charter. The EU presidency, Norway, Estonia and the US also noted that their support of the CIS as observer to the UN should not entail as support for authorisation by the Security Council of enforcement or other action by the CIS. ${ }^{24}$

It should not be construed that the UNMOT (United Nations Missions of Observers in Tajikistan) cooperated closely with a peacekeeping force of the CIS in 1997 to help promote peace and reconciliation and assist in implementing the peace agreement with Tajik pro-Islamic traditionalists is an evidence of the UN's recognition of the CIS as a regional organisation. Similar cooperation took place in Georgia in 1996 as UNOMIG (United Nations Observers Mission in Georgia). The fighting parties agreed to the deployment of a peacekeeping force of the CIS to monitor compliance with the peace agreement. In the meantime UNOMIG did the same thing in addition to observing the operation of the

${ }^{23}$ Foreign Policy Document No: 258, The Commonwealth of Independent States: International Status, Russia/FSU Section (UK), at [htp://www.home/rjw/texts/cis.status], September 1994, p. 1. ${ }^{24}$ Ibid. 
CIS force. ${ }^{25}$ This example also does not imply that the UN de jure recognizes the CIS as regional organization just as NATO and OSCE.

\section{- The CIS does not resemble confederal systems}

In the past there were various examples of confederation models; e.g. the Rhine Confederation (1806-1813), New England Confederation (1778-1887), North German Confederation (18151866) and Helvetic Confederation (1816-1848). Today, although the official name of Switzerland is the Swiss Confederation (Confederation Helvetique - $\mathrm{CHI}$ ), it is a federation in technical terms. Presently, there is only one confederation in the world which was established in 1982, namely, the Senegambian Confederation. ${ }^{26}$ When it comes to the CIS, could one attribute 'a modern version of confederation' to it?

Early comments on the CIS referred to it as "not a successor state to the former Soviet Union but a confederation of independent republics". ${ }^{27}$ In the heydays of the integration, some commentators treated the CIS as an intergovernmental organisation

${ }^{25}$ Basic Facts About the United Nations, New York, UN Publications, 1998, pp. 104-105.

26"The joint institutions of the Senegambian Confederation comprise: (1) The President and Vice-President which decide on the mutual agreement on the policy of the Confederation on matters of defence and security, coordinate the policies of the confederated States on matters within the responsibilities of the Confederation, make appointments to all confederal posts. The President of the Confederation commands the Armed Forces and the Security Forces of the Confederation; (2) The Council of Ministers, whose members are appointed by the President of the Confederation in agreement with the Vice-President; (3) The Confederal Parliament, whose members are selected among the members of the national parliaments of the confederated States". See the texts of the founding agreements of the Senegambian Confederation in ILM, Vol. 21, 1982, pp. 44-47; ILM, Vol. 22, 1983, pp. 260-286, quoted in Voitovich, An Emerging Institutional Model, p. 418.

${ }^{27}$ Butterworth, Successor States- Property Rights, p. 660. 
with the elements of confederation. ${ }^{28}$ For example, Danilenko says the CIS is a version of Russian federalism in the form of a confederate model. ${ }^{29}$ However, the CIS Charter declined to use the term "confederation" with regard to the Commonwealth's status, because of the fear that it was too premature to establish a Statelike formation. Nevertheless, the suggested institutional model of the CIS has parallels with a loose confederation in the sense that it is a purpose-oriented union of sovereign states with coordinating organs of its own. The institutional structure of the CIS in the Charter's version is more ramified than that of the classical confederations, but less centralised than the Senegambian Confederation. ${ }^{30}$

In addition to this, unlike confederations, the Commonwealth does not hinge on a common foreign policy. For example, the Russian-Ukrainian dispute over the future of the Black Sea Fleet and definitions of "strategic forces" brought to surface all the fragility of the Commonwealth. ${ }^{31}$ In the Black Sea Fleet example, it is seen that CIS decision-making system does not resemble confederal form, since Russia and Ukraine violated the CIS Agreement with the Black Sea Fleet Agreement inasmuch as two of them did not take the views of the rest of the CIS members in deciding to jointly control the Fleet and thereby by acting outside the proscribed CIS methods and by denying to hand over part of the Fleet to other states to develop their own navies. ${ }^{32}$

Therefore, one year after the conclusion of the CIS Charter, it was turned into a very loose document. By mid-1992, the idea of a "Eurasian confederation" lost a lot of its initial appeal in Russia as well as other states. This was galvanised by Russian attitude. Apart from clearly supporting the "confederationist" approach in some

${ }^{28} \mathrm{Kux}$, Confederalism and Stability in the Commonwealth of Independent States, p. 387.

${ }^{29}$ Danilenko, The Confederate Model of the Commonwealth of Independent State, pp. 367-386.

${ }^{30}$ Voitovich, An Emerging Institutional Model, p. 418.

${ }^{31}$ A. Kortunov, 'Russia and the "Near Abroad": Looking for a Model Relationship', [http://emmaf2.isuisse.com/emmaf2/USRUS/usrp7.html], 8 March 2001.

${ }^{32}$ Butterworth, Successor States- Property Rights, p. 668. 
cases, the Supreme Soviet took very rigid nationalist positions. For instance, on 9 July 1993, a joint session of the Russian Supreme Soviet passed a resolution calling for the reassertion of Russian sovereignty over the Crimean port of Sevastopol and overturning the Yeltsin-Kravchuk agreement to divide the Black Sea Fleet. ${ }^{33}$ In sum, the concept of a "Eurasian confederation" turned out to be naive and impractical, strikingly similar to the old Gorbachev's idea of a "common European home".34

\section{- The CIS cannot be compared with the Commonwealth or international organisation of La Francophonie}

To a degree, the CIS resembles the (British) Commonwealth $^{35}$ or La Francophonie ${ }^{36}$ or the Community of

${ }^{33}$ Even one hailed its view as disintegration, see Young, Living in a MultiPolar World, pp. 6 et seq.

${ }^{34}$ Kortunov, Russia and the Near Abroad.

${ }^{35}$ The Commonwealth (formerly known as Commonwealth of Nations (1931-46) and British Commonwealth of Nations), is a free association of sovereign states comprising Great Britain and a number of its former dependencies who have chosen to maintain ties of friendship and practical cooperation and who acknowledge the British monarch as symbolic head of their association. Spread over every continent and ocean, the Commonwealth is a unique voluntary association of independent sovereign states of 54. It is therefore not confined a specific region. Its 1.7 billion people account for 30 per cent of the world's population. It is multicultural, multireligious and multilanguage organization. Today it helps to advance democracy, human rights, sustainable economic and social development within its member countries and beyond. Commonwealth leaders established the Commonwealth Secretariat in London in 1971. In 1991, the Harare Commonwealth Declaration set the association firmly on a new course for a new century: that of promoting democracy and good governance, human rights and the rule of law, and sustainable economic and social development. 1997 summit in Edinburgh, Commonwealth leaders agreed on a set of economic principles and practical activities to promote trade, investment and sustainable development. Today the Commonwealth continues to be active in global affairs, helping to build consensus around the world. It manages a Joint Commonwealth Office in New York City in order that small member countries can afford to have permanent missions to the United Nations. The Commonwealth has also been instrumental in launching a series of 
Portuguese-Speaking Countries. ${ }^{37}$ Prima facie, they are the consequences of the break-up of former colonial powers. In essence, there are some discrepancies.

Even though some argue that by the very term "Commonwealth", the founders conceived that the structure of the Commonwealth of ex-British colonies was viable to create a minimally institutionalised association with limited powers of its own, contrary to the strongly centralized former Soviet Union. But as many would yield, the term commonwealth is of a bad connotation. 38 The term intrinsically brings one's mind

regional investment funds to stimulate pan-Commonwealth and intraCommonwealth trade and investment. For further information, see [http://www.thecommonwealth.org/], 15 March 2001.

${ }^{36}$ Dating back to the 1880 s, the Association of French Speaking Countries, which has 500 million people under its umbrella, is comprised of 51 states. It acquired observer status at the EU, OAU, UNECA. It has the Intergovernmental Agency of the Francophonie, the Parliamentary Assembly. It has a Conference of the Heads of State and Government and a secretary-general elected for 4 years. For more information about the organisation see, [http://www.francophonie.org], 16 March 2001.

${ }^{37}$ Founded in June 1996 among Portugal and six of its former colonies (Angola, Brazil, Cape Verde, Guinea-Bissau, Mozambique, and São Tomé and Príncipe), it was clearly said that it was modelled after the Commonwealth of Nations and International Organisation of La Francophonie (or Association of French-speaking nations).

${ }^{38}$ In western languages, the term was often used by $17^{\text {th }}$ century writers, for example, Thomas Hobbes and John Locke, to signify the concept of the organized political community. Specifically, commonwealth served as the label of the Cromwellian regime in Great Britain (1649-60). Modern usage has further extended the term. Thus, the Australian colonies were federated as states in 1900 under the official title of the Commonwealth of Australia. Then, as various British colonies evolved from a status subordinate to the United Kingdom into an association of equal partners, the new relationship was named a Commonwealth. After India became a republic and chose to remain inside the Commonwealth, the phrase 'head of the Commonwealth' was substituted for 'Emperor of India' in the royal title, and Queen Elizabeth II was so crowned in 1953. In the United States, commonwealth has continued to be the official description of four states (Kentucky, Massachusetts, Pennsylvania, and Virginia). It confers no distinction, other than in name, from the other states; see 'The Commonwealth' at [http://www.britannica.com], 17 March 2001. 
colonization or implies that Russia similar to Britain was subjugating other members.

When the scope of the aims of the CIS are considered, they are far more diverse than the British Commonwealth and $L a$ Francophonie. Moreover, unlike the establishment of the CIS with a Charter, ${ }^{39}$ the British Commonwealth Association has no constitution or charter. That is, it was not established by an international agreement. ${ }^{40}$ Unlike unequal status of the British Commonwealth members (the sovereign of the United Kingdom remains "Head of the Commonwealth", and some members are dependent colonial territories) the CIS rests on the principle of sovereign equality of its members (even though, there are different categories of CIS membership). Further, compared to the British Commonwealth organizational structure (which has a Secretariat, established in 1965 , that has no executive functions ${ }^{4}$ ), the

${ }^{39}$ Charter has a double facet: it both refers to binding constitutional documents such as the UN Charter and to non-binding agreements such as the 1991 Paris Charter of the OSCE. The CIS Charter is the second-type document.

${ }^{40}$ It was established by the Royal Titles Act of 1953 . The 1965 Agreed Memorandum and 1971 Singapore Declaration were formulated after the formation of the organisation. Because of this, Muller does not regard the Commonwealth as an international organisation. A. Muller, 'International Organisations and their Host States', 1995, p. 4, cited in A. Duxbury, 'Rejuvenating the Commonwealth- The Human Rights Remedy', International and Comparative Law Quarterly, Vol. 46 (1), January 1997, pp. 344 and 346. Contrary view argues that the organisation fails to fulfil the prerequisites necessary to command the status of an international organisation. See W. Dale, 'Is the Commonwealth an International Organisation?' International Comparative Law Quarterly, Vol. 31, 1982, p. 451. Opposite to this, Chan says it has both organisational character and international personality, see S. Chan, 'The Commonwealth as an International Organisation' in J. Alner (ed.), Twelve Years of the Commonwealth Diplomatic History, 1992, p. 3, cited in Duxbury, ibid., p. 346.

${ }^{41}$ Members commit themselves to the statements of beliefs set out by Heads of Government. The basis of these is the Declaration of Commonwealth Principles agreed at Singapore in 1971, and reaffirmed in the Harare Declaration of 1991, which describes the Commonwealth as a voluntary association of sovereign independent states, each responsible for its own 
emerging institutional model of the CIS is likely to evolve towards a more elaborate and cohesive structure. ${ }^{42}$ Similar views can be reiterated for the La Francophonie, since it was set up by the 1946 French Constitution and restructured by the 1958 Constitution rather than an international agreement such as a charter. ${ }^{43}$

\section{- The CIS is not identical to the Council of Europe, the OSCE or NATO}

The original intention in December 1991 was to maintain a unified security structure in the post-Soviet region. ${ }^{44}$ The result was a mixture of NATO and the OSCE. But a new NATO-type alliance system, proposed by Russia in Minsk and Alma-Ata in December 1991, was seen an attempt to recover the position of Russia's regional influence lost with the collapse of the USSR. ${ }^{45}$ The fact that Russian troops are deployed in many of the former Soviet republics as "peace-keeping" forces under CIS commitments ${ }^{46}$ should not convince one to equate the CIS with NATO. Even though the Alma-Ata agreements envisaged preservation of the "common military-strategic space", it was rejected by Ukraine, Azerbaijan and Moldova, while Uzbekistan and Turkmenistan insisted on building their national armies before any military integration with other CIS states. In May 1992 Russia itself had to announce that it started its own national army beyond the structures of the CIS Supreme Command.

policies, consulting and co-operating in the interests of their peoples and in the promotion of international understanding and world peace.

${ }^{42}$ Voitovich, An Emerging Institutional Model, p. 418.

${ }^{43} \mathrm{H}$. Eroğlu, Devletler Umumi Hukuku, $3^{\text {rd }}$ edition, Ankara, Adım Yayıncilık, 1991, p. 113. Eroğlu, p. 114, says since it was not set up by an international agreement, it is not a confederation; neither is it a federation because member states are devolved upon the right to terminate their membership.

${ }^{44}$ Sakwa/Webber, The Commonwealth of Independent States, p. 379.

${ }^{45}$ For further view see John P. Willerton, 'Symposium: European Security on the Threshold of the $21^{\text {st }}$ Century: Current Development and Future Challenge: Russian Security Interests and the CIS', Willamette Journal of International Law \& Dispute Resolution, Vol. 5, 1997, pp. 29-53.

${ }^{46}$ Ibid. 
As far as the goals of the CIS are concerned, it is to be seen that parallel activities with notable organisations such as the Council of Europe, NATO and the OSCE are there. However, the CIS's activities encompasses those of others. For example the Charter contains as diverse provisions as ensuring human rights and basic freedoms, cooperation in developing transport and communication systems, protection of health and environment, social and migration policy issues, combating organized crime, protection of external boundaries, etc.

Taken human rights example, the Council of Europe is famous for its human rights mechanism. The founders of the CIS appear to have impressed by its dazzling performance. However, when one gazes at how human rights mechanism operates, one sees the difference. Weakness can be run into in the attempts to establish a new regional human rights system within the CIS on the basis of the Convention on Fundamental Rights and Freedoms. ${ }^{47}$ Even though there is a machinery called Human Rights Commission whose task would be to monitor implementation of the provisions of the Convention, there exists no strong enforcement system. As its decisions are not legally binding, the Commission is likely to fail to protect human rights within domestic legal systems.

As one could make out, the CIS was conceptualised as a consensus-based consultative forum. The 12 members have held always radically divergent conceptions of the organisation's shape and purpose. While they have been always sensitive to the protection of their newly-acquired sovereignty, perceptions of the degree to which the CIS can be made to act in ways that are materially beneficial and consonant with independent statehood vary from case to case.

\footnotetext{
${ }^{47}$ For an English language of the CIS Convention on Human Rights, see Human Rights Law Journal, Vol. 17, 1996, p. 159; cited in Danilenko, Implementation of International Law, p. 67.
} 


\section{4- The CIS vs. the EU: Consensualism vs. Supranationalism}

Having seen that the CIS is clearly different from other organisations, one organisation remains for comparison: the EU. 48 Making such a comparison is important because the CIS Charter appears to have been envisioned to be something akin to the 1957 Treaty of Rome or even the 1992 Maastricht Treaty, as it was to create supranational bodies and authorize them to oversee integration on a variety of questions. ${ }^{49}$ However, the CIS is so much different from the EU. The crux of difference lies in the fact that whereas the CIS is a remarkable example of intergovernmentalism and consensualism, the EU is par excellence of a supranational system. This is where the CIS history is crammed with unsuccessful attempts to create a meaningful integration similar to its contemporaneous. In economic terms, as the future of the CIS was seen by "confederalists" as of another European Community, it was thought that economic integration would become the essential cohesion agent keeping the republics together. ${ }^{50}$ However, the EU's institutional structure is an antipode of the CIS model.

As the former satellites were scared of the notorious experience of the Soviet Union's central authorities, they were quite afraid of creating a powerful institution which could threaten their fledgling sovereignty. Due to political and historical reasons, the CIS countries were not ready to make a substantial transfer of their sovereignty to supranational institutions. In the end, the result was not surprising: Each member state was going to determine unilaterally its commitment. Each member would choose the level of commitment that best fits its national interests. Member states possess unilateral discretion in determining both their level of involvement in a given issue area and the degree to which they commit to negotiated multilateral policy outcomes. Areas of negotiation and potential joint activity span economic (including

${ }^{48}$ For reference see Comparing the CIS and the EU, Moscow, Nestor Academic Publishers, 1997. It is also published as 'International Law Bulletin (Russia and CIS)', Special Supplement to Moscow Journal of International Law, Vol. 13 (4), 2000.

${ }^{49}$ Kubicek, End of the Line.

${ }^{50}$ Olcott, Sovereignty and the Near Abroad, p. 353. 
institutional/structural matters) and social (e.g., public health and the environment) areas, communications and transportation systems, and foreign and security issues. ${ }^{51}$

To this end, the decision-making system was so loosely drafted that no member state which is either disinterested in the issue, or does not want to participate in a given regulation, could be forced by the other member states to comply with a Council's decision. Should a member state be interested in the matter, it is entitled to veto an unacceptable decision. Should a member state declare that it has no interest in the question under consideration, this does not block the decision to be adopted at large. But the non-interested member state is left on its own. To recapitulate differently, the crux of consensualism is that the abstentions of one or a few member states do not void the decision at large. For example, the CIS Charter was adopted by seven of the ten participating States. 52 However, the consensual rule can hardly work provided a decision be taken against a member state in the cases of dispute settlement or the use of sanctions.

What came out at the end of the day is that despite the fact that more than 200 arrangements on economic, military, ecological, social and other matters were concluded, their quantity does not commensurate with the expected quality. A plethora of decisions reached within the CIS did not have teeth strong enough because of increasing disagreements among the members, which in turn fostered mutual distrust. After all, this nurtured bilateralism: Member states, predominantly Ukraine, evidently opted for bilateral treaties, while others favoured the establishment of more compact sub-regional unions, such as the Central Asian common market which was established in early January 1993.53 Other

\footnotetext{
51 Willerton, Symposium: European Security.

${ }^{52}$ E.g by 1994, the CIS adopted 270 documents, of which one member had ratified only 40 , another 140 , and yet another 150 . By early 1995 , the number of unratified documents had come to about 400 .

${ }^{53}$ The main example of attempted sub-regional integration outside the framework of the CIS is the Central Asian Economic Community (CAEC-prior to July 1998 known as the Central Asian Union), established in December 1994, and comprising Kazakhstan, Uzbekistan, Kyrgyzstan and later Tajikistan (which was granted entry in March 1998). This grouping has since established a number of coordinating bodies:
} 
examples wherein member states, one way or another, took part in are such informal multilateral economic relationships as Economic Cooperation Organization (ECO 1985), Council of Baltic Sea States (CBSS 1992), Black Sea Economic Cooperation (BSEC 1992), the Barents Euro-Arctic Council (BEAC 1993), Aral Sea Agreement (1994), The Arctic Council (1996), Union of Belarus and Russia (UBR 1997), GUUAM (grouping comprising Georgia, Ukraine, Uzbekistan, Azerbaijan, Moldova, 1997). Last but not least, in December 1998 Yeltsin and Belarus President Lukashenko signed a bilateral agreement to begin unification of the two countries' currencies and create a common citizenship.

Another example of the intergovernmentalism is that states are allowed to make reservations and explanatory declarations on the Charter articles relating to such organs as the Council of Commanders of Border Troops, the Economic Court, the Coordinating-Consultative Committee, the Council of Ministers of Defence and the High Command of the United Armed Forces, the Commission on Human Rights and the Inter-Parliamentary Assembly. ${ }^{54}$

As the Charter is a non-binding instrument, states are free to dissent from consensus positions, in effect protecting their national sovereignty while minimizing any loss of long-term manoeuvrability. Some states consistently minimized their commitment to CIS-sponsored economic and security agreements

Councils of heads of state, of prime ministers and foreign ministers, all of which have held regular meetings. It has made some headway on the joint management of scarce water resources and has undertaken move toward joint investment projects and a regional customs union. Tentative steps have also been taken regarding military cooperation.

${ }^{54}$ Payments Unions is a good illustration of this: In 1993, failure to establish a payments union and coordinate currency emissions led to the collapse of the 'ruble zone'. Turkmenistan and Azerbaijan refused to participate in the payments union. On the other hand, Ukraine used to participate only after the introduction of its national currency and indicated that it intended to retain full national control over its monetary policy. Apart from Uzbekistan, the rest of the member states put forward amendments or appended reservations that significantly diluted the Interstate Economic Committee's powers. Pioneered by Ukraine, some states articulated specifically that IEC decisions could not supersede national legislation. see Olcott, Sovereignty and the Near Abroad. 
(e.g., Ukraine and Moldova), while others exhibited involvement in most, if not all, multilateral arrangements (e.g., Armenia and Kazakhstan). They simultaneously manoeuvred to limit the development of any supra-state structures that might have oversight functions. ${ }^{55}$ At the beginning there was a reaction towards erosion of sovereignty. As one Ukrainian official stated at the time, "We don't want to have any suprastate structures playing the role of a 'drill sergeant' who would give orders to the Commonwealth countries.". 56 Therefore the CIS Charter was so loose that it did not oblige members to do anything. ${ }^{57}$ It appears that what was in the minds of the founders of the CIS was not EU-like institution but was something like EFTA, a truly intergovernmental model.

On the other part of the spectrum, had the founders of the CIS managed to devise a supranational decision-making process, today the CIS would have been rather successful. This facet of supranationality, called as decisional (political/institutional) supranationalism, means that the member states abstain from vetoing proposals and try to achieve agreement by way of downgrading their national interests. ${ }^{58}$ In this case, the CIS would have been strong enough to dictate its will to the states that brought it into existence, without their consent. At this juncture, there is a clear distinction between a confederation, where limited sovereignty is delegated, and supranationalism, where sovereignty no longer exists. In this sense, the CIS or United Nations is similar to a confederation. It has left sovereignty intact, but has also added to international law. It governs by consent of the member states. ${ }^{59}$

The CIS founders should not take refuge in the excuse that nothing better could have been devised in the light of the then existing circumstances. When looked at the European experience, it is seen that at the beginning of the EEC, the European states were not unified and did not want to give all powers to supranational

55 Willerton, Symposium: European Security.

${ }^{56}$ Kubicek, End of the Line, p. 15.

${ }^{57}$ Ibid.

${ }^{58}$ See e.g. J. Steiner, The EC Law, 4th ed., London, Blackstone, 1994, pp. 6-7.

$59 \mathrm{cf}$. M. A. Korolev, 'Supranationalism in the Eyes of International Law', Moscow Journal of International Law, Vol. 2 (2), 1997, pp. 1-10. 
organs. In other words, in the European integration the decisional supranationalism was not steady all the time. But Community organs overcame hurdles. From the establishment of the Community in 1957 to the Luxembourg Accords of 1966, the Community and Council were predominant institutions. Establishment of Customs Union, the elaboration of the provisions of four freedoms and defining common policies were all undertaken by the Commission and the Council. At this stage there was a high level of decisional supranationalism. Nevertheless, the member states reacted to these developments with the signing of the 1966 Luxembourg Accords aiming to bring about an intrusion of diplomatic control at all levels of the decisional process. ${ }^{60}$

Until the 1986 Single European Act, this was the case. In this period, there was a gradual diminution in the decision making process. This was partly because, according to the Accords, the member states might insist on unanimous decision, where vital national interests were at risk. Although the Accords did not have the force of law, in many cases the Council accepted it as a Community norm. In this period, there were also other reasons for decline in the decision-making procedure: The independence and autonomous policy and decision-making role of the intergovernmental institutions and the weight of nonintergovernmental institutions in pluri-institutional decisionmaking process were declining and in the execution or detailed legislative implementation of Community policies, there had been a shift to member state domination.

After the 1986 Single European Act (SEA), an impressive revival of a strong decisional supranationalism has seen, which was nearly forgotten after the 1966 Accord. The most meaningful originality of the SEA was that it enlarged the sphere of areas in which the majority of legislation being essential to complete the internal market, are to be enacted by qualified majority. There were also some institutional novelties strengthening decisional supranationalism: the Parliament, for example, increased its influence in the decision-making process as well as its role concerning the Community budget; the members of the

${ }^{60}$ See Heathcote, 'The Crisis of European Supranationality', Journal of Common Market Studies, Vol. 5, 1966, p. 140. 
Commission were chosen among independent figures and the Commission's recommendations, after the SEA could hardly be amended by the Council. Before the SEA, the guardian of the Treaties was the Court, but the Act entitled the Commission to act as a "watch-dog" of the Community. In the end, what the SEA has achieved was no more than a structural "perestroika" in institutional and political frameworks of the Community. The tendency towards ever closer union went on to enact the 1992 Treaty on European Union (TEU), 1997 Amsterdam Treaty and 2000 Nice Treaty. However, one must admit that certain policy areas were taken out of the hands of the EC institutions altogether. This illustrates the continuing ambivalence of the direction of European integration. ${ }^{61}$

As can be seen decisional supranationalism was not easily achieved. It was a gradual and decisive struggle achieved over the years. The most important mistake of the CIS integration was that its organs were not vested in supranational powers while they were required to function as if they have been granted such suprapowers, as the CIS's appearance on paper is rather similar to the EU.

The leaders ignored the fact that EU's success lies in its gradual evolution, during which member states were forced to relinquish their sovereignty to Community organs. Hence, the first lesson to be learnt from the European integration is that its evolution was systematic and gradual. Core issues were tackled at first, and later, subtle issues were taken on board. For example, the Maastricht Treaty was the third attempt to create a monetary and economic union in Western Europe - after the Werner Plan, which failed in the early 1970 s.

Another example is that the TEU originates from the need for gradual evolution from a customs union to a common market and then to an economic and monetary union. The Treaty's logical scheme of gradual construction was not observed. The leaders could not make out that one cannot talk about common currency if there is not even a real customs union. Therefore, attempts at

${ }^{61}$ A. Charlesworth, \& H. Cullen, European Community Law, London, Pitman Publishing, 1994, p. 41. 
reforming the "ruble zone" in the absence of the necessary preceding stage of integration led this "zone" to ultimate failure. ${ }^{62}$

In the mid-1980s, when the European Economic Community was also called the "Common Market", no common market as such existed in practice. There was a customs union, but there were still customs inspections at borders; there was free movement of citizens in the region, but there were still passport checks, and so forth. Member states therefore sustained serious economic losses. After studying the problem, EU representatives compiled a list of essentially 300 legislative acts that had to be passed to eliminate "physical, technical, and tax barriers" to the movement of goods, services, capital, and citizens. This was the essence of the program for creating the common market. ${ }^{63}$

Consequently, one of the most important lessons of the European experience (British and Italian leave of the EMS system) was the importance of consensus and compromise, in keeping with the fundamental principle that no one country can be forcibly drawn into integration mechanisms, just as no one country is entitled to block the movement of other. 64

If the projected Euroasian Economic Union is desired to be successful, and the CIS is wanted to be transformed from its present commonwealth structure into a confederation of states, in no way is there any alternative other than the member states surrendering large parts of their sovereignty to a supranational parliament charged with the development of a common economic policy, as well as common defence. ${ }^{65}$

In other words, the universal peculiarities inherent in the integration process were not fully heeded. The CIS political analysts should elicit lessons from how the EC Commission and the EU Council are formed and how they were the watch-dog of EC

${ }^{62}$ A. Osterland, 'Russian Overture', Financial World, Vol. 164 (7), 14 March 1995, pp. 24-26.

${ }^{63}$ Ibid.

${ }^{64}$ Ibid.

$65 \mathrm{cf}$. Olcott, Sovereignty and the Near Abroad. 
interests and how purposefully moved ahead towards "ever closer union" despite conflict and crises.

The way the CIS was conceived in the early 1990s has ignited widespread curiosity, amazement and debate over whether such a organisational cloning would succeed in giving birth to a viable and workable model for future integration efforts. A decade-lasting experience proved that cloning the EU model in the CIS body was unsuccessful. If the founders of the CIS do really want to rejuvenate it, they should yield to the fact that the EU is not a pertinent example to start with. Lukashenko's idea -to create powerful institutions to implement and enforce all previous agreements and re-establish democratic centralism- is no better because it does not get round the question of sovereignty. ${ }^{66}$ Something more akin to the North American Free Trade Agreement might be plausible, but this would obviously limit the areas of CIS jurisdiction and not require political institutionalization. ${ }^{67}$ At any rate, until there is a definitive concept of what is desirable and possible, the CIS will remain in its current state of limbo. However, it is unclear how much longer we will retain faith in its recoverability or reformability. ${ }^{68}$

\section{5- Law As a Cohesion Agent: The CIS Economic Court vs. the European Court of Justice (ECJ)}

In the 1950s, the member states of the EEC intended to create a court that could not significantly compromise national sovereignty or national interest, but the ECJ changed the EU legal system, fundamentally undermining member state control over the Court. ${ }^{69}$ It is thanks to the ECJ that the European integration managed to flourish in the course of time. The Court actively made

${ }^{66}$ Kubicek, End of the Line.

${ }^{67}$ Ibid.

${ }^{68}$ Ibid.; Voitovich, An Emerging Institutional Model, p. 418; S. Blank, 'Russia, NATO Enlargement and the Baltic States', World Affairs, Vol. 160 (3), 1998, p. 115.

${ }^{69}$ A., Karen, 'Who are the "Masters of the Treaty"?: European Governments and the European Court of Justice', International Organization, Vol. 52 (1) Winter 1998, pp. 121-147. 
use of law as a cohesion agent when it saw the political inertia which occurred in the early 1960 s, shortly after "the euphoria of the first confident years after the Treaties of Rome" and after "the deadlock over de Gaulle's challenge to the Commission's supranational presentations and Community method". ${ }^{70}$

The diminution in the decision-making process and the impossibility of getting closer by means of political integration led to the emergence of the Court's activism known as normative supranationalism. Starting from the mid-1960s, a growing gap between the reality of economic integration and the conceptual and political framework bore the principals of direct effect, supremacy and preemption as adhesive elements to fill this growing gap in the political framework of the Community. Therefore, through direct effect of the EC law and supremacy of the Community law principles, the Court acted as a partial agent and an advocate of the EC.

What makes the European Community a supranational organisation is not only how the Community decisions are prepared, discussed and finally accepted, but how the Community policies and Community law are implemented. Legally speaking, the Community norms take effective precedence over national ones. In this hierarchy Community legislation is both directly applicable in the member states and is of supremacy over national laws.

When it comes to the CIS Court, one should subscribe to the fact that such a legal power is given to the CIS Economic Court. The 1993 Treaty on the Creation of an Economic Union which have foreseen trade association, a customs union, a common market based on four freedoms and a monetary union (which is very similar to the Treaty of Rome) requires in Article 25 the supremacy of the 1993 Treaty: "If the present Treaty contains norms and rules other than those provided by national legislation,

${ }^{70} \mathrm{~W}$. Wallace, 'Introduction: The Dynamics of European Integration' in W. Wallace (ed.), The Dynamics of European Integration, London, The Institute of International Affairs, 1990, p. 3. 
the rules and norms of international law and the present Treaty shall be applied". ${ }^{71}$

This implies that there are some supranational elements in it. However there is not an effective mechanism to make this provision true. It is not clear from the CIS Charter if resort to the Economic Court in the event of an economic dispute is mandatory or depends on the discretion of the disputing parties. In the latter case, which is more likely, it will have to be specified whether a litigation in the Court can be initiated by a unilateral request of any of the disputants or only by their mutual consent. Finally, it is not clear what legal entities can be considered as "disputing parties"; only the member states or also their nationals directly involved in economic interactions. ${ }^{72}$

Therefore, the CIS remains "a fairly loose organisation of states" as a result of the decision of the member states to adopt the model of multi-speed and multi-option integration. ${ }^{73}$ Therefore member states are free to choose the level and pace of integration into the existing CIS structures. Since there is no institution like the ECJ which developed the direct effect and supremacy principles through case-law, there was no way to advance the CIS ideals in cases when the member states failed to adhere treaty provisions. That is to say, in addition to the weakness of decision-making organs (Councils of Heads of State and Government) in cases when CIS members simply ignored treaty provisions and did not accept necessary changes to be made for an ever closer CIS, the CIS structure lacked also a fully integrated judicial organ capable of settling disputes among the members. One should not be misled by the existence of the Economic Court either, in that as far as the 1992 Statute of the Economic Court is concerned, the Court is not an integral part of the CIS Charter. The CIS members are not ipso facto parties to the Statue of the Economic Court. ${ }^{74}$

${ }^{71}$ Danilenko, Implementation of International Law, p. 67; ILM, Vol. 34, 1995; cited in Danilenko, p. 67.

${ }^{72}$ Voitovich, An Emerging Institutional Model, p. 148.

${ }^{73}$ Danilenko, Implementation of International Law, p. 67.

${ }^{74}$ Three states have not become party to the Statute: Turkmenistan, Georgia and Ukraine. Note that Ukraine became an associate member of the Economic Union. See G. M. Danilenko, 'The Economic Court of the 
The Economic Court has been vested in jurisdiction over "interstate economic disputes" including those concerning "the conformity of normative and other acts of member states of the Commonwealth". ${ }^{75}$ The jurisprudence and the actual impact of the Economic Court on the cooperation of the domestic legal systems of CIS states remains marginal. Until 1998, the Court had only dealt with five cases. None of which however is concerned with "the conformity of normative and other acts of member states of the Commonwealth on economic issues with the agreements and other acts of the Commonwealth".

\section{Conclusion}

The CIS was established as a "building without a foundation". ${ }^{76}$ While Russia has always tried to use the CIS as a launching pad to attain its aims and for its foreign policy ends, it underestimated the fact that a full-fledged economic and monetary union is commensurate with supranationality at institutional and legal spheres. Successful attempts at regional cooperation require an organisational framework characterised by a comprehensive regional membership, an apt institutional machinery and effective procedures for decision making and implementation. The CIS has been marginalised due to several problems:

1) Legally speaking, the CIS lacks a definite mould. Unfortunately, there is no theoretical guide or historical precedent for how one might move from a unified state to a confederation or federation of separate states. The gravity of nationalism and

Commonwealth of Independent States', New York University Journal of International Law, Vol. 31 (4), 1999, p. 893. For further information, see I. V. Fisenko, 'Mechanisms of Settling Disputes Within the CIS and the Role of the CIS Economic Court', Moscow Journal of International Law, Vol. 2 (2), 1997, pp. 67-73.

${ }^{75}$ Danilenko, Implementation of International Law, p. 67.

${ }^{76}$ The former Minister of CIS Affairs Anatoly Adamishin's words, quoted in A. Malashenko, 'Putin in the Post-Soviet Space: Revisiting the Old or Starting New Relationships?', Briefing Papers, Vol. 2 (7), 2000, see at [http://pubs.carnegie.ru/english/briefings/2000/issue07-00.asp], 19 March 2001. 
jealousy of sovereignty lead one to believe that the CIS will never slumber. ${ }^{77}$ As an organisation, its powers, competence, aims are not clear enough. This is not because these have not been dealt with in constituting documents of the CIS; but because its legal definition has not been articulated by the fathers of the organisation. To put it clearly, no one, arguably, could give a satisfactorily answer as to whether the CIS is an organisation similar or akin to the Commonwealth, or the International Organisation of $L a$ Francophonie, the EU, or the Council of Europe.

2) Voluntary participation to the CIS bodies. For example, Ukraine, Turkmenistan and Uzbekistan did not participate in the CIS' Interparliamentary Assembly. Azerbaijan, Turkmenistan and Ukraine did not become a party to the dispute settlement system through the Economic Court; and these states together with Moldova have kept themselves aloof from CIS military bodies. Taking CIS structures as a whole, the greatest non-participation has occurred among Turkmenistan (in 31 bodies), Georgia (28), Azerbaijan (22), Ukraine (16), Moldova (12) and Uzbekistan (8). This voluntary participation system applies also to treaty-making process: Out of the 886 documents adopted by the CHS and CHG by March 1998, only 130 had been signed by all 12 member states. ${ }^{78}$

3) Third layer of problems relates to decision making and implementation. At the apex of the CIS (the CHS and the CHG) decisions are taken, according to CIS documentation, by consensus. It is important to bear in mind that regional cooperation and far-fetched integration process necessitates dynamic and lengthy intergovernmental policy struggles, often complex consensus-building formulas, and piecemeal policy implementation. ${ }^{79}$

\footnotetext{
${ }^{77}$ Kubicek, End of the Line.

${ }^{78}$ Sakwa/Webber, The Commonwealth of Independent States, footenote 120.

${ }^{79}$ H. A. Welsh \& John P. Willerton, "Regional cooperation and the CIS: West European Lessons and post-Soviet experience", International Politics, Vol. 34 (1), March 1997, pp. 33-61.
} 
4) The weakness of certain CIS organs such as the Inter-State Bank and the Economic Court resulted in the low levels of functional cooperation. As no CIS institution was devolved upon by the CIS Charter such a power to counteract in cases of national breaches, its most basic ideals, such as respecting state sovereignty, renouncing force or coercion to resolve conflicts, and integrating and coordinating economic programs, have consistently been breached more than practiced. ${ }^{80}$

5) Attempts to emulate the European Community should have taken into fact that success also lies in that countries which are economic, political and technological counterparts, whereas the countries that are party to the newly-formed Eurasian Economic Community are in no position to boast of their economic development. In such a situation, there can be no talk of equal cooperation between its members. Bringing well-off countries closer together is a completely different thing from a union of poor countries that can hardly manage by themselves. ${ }^{81}$ Hence, the fate of the CIS is contingent upon whether the development of the necessary preconditions for EC-like model will be made without fail.

At the end of the day what can be said is that having member states seemed to believe that obstacles to developing the CIS could not be easily surmounted, 82 they seek now other realistic alternative small organisational models within which they could maximize their political and economic ends. Hence, some CIS countries set up separate organizations such as unions of five (GUUAM) or the EEC instead of realizing the CIS potential to the full and using its opportunities for economic cooperation. ${ }^{83}$ Under these circumstances, the future of the CIS is very gloomy. These sub-regional bodies have accelerated the territorial fragmentation

\footnotetext{
${ }^{80} \mathrm{Kubicek}$, End of the Line.

${ }^{81}$ Uzbek Newspaper Halq So'zi, 'Uzbek Party Leaders Slam Eurasian Economic Community', 25 October 2000, see at [http://www.uznews.com/news/10-26_00/uzb_par.html], 3 March 2001.

${ }^{82} \mathrm{~T}$. D. Valovaia, 'Economic and Monetary Union: Properties of its Formation,' Russian \& East European Finance \& Trade, Vol. 31 (5), September-October 1995, pp. 7-18.

${ }^{83} \mathrm{Halq}$ So'zi, ibid.
} 
of the CIS area and cannot but undermine any broadly based approach to developing some sort of supra-national Commonwealth community. Member states are likely to confine the CIS to the common lowest denominators and would not support any measures that would grant it supranational powers. ${ }^{84}$

The answer of whether the Eurasian Economic Community is "nothing but a pipe dream",85 or will likely to expand the cooperation of the participating countries and take the worthy place among other regional economic organisations, rests on how well a decade-long interaction of politics, law and economics are to be intermingled. As long as the new EEC takes into account the European dynamics rather than that of the Soviet, it is likely that it will flourish in the future. Otherwise, it could be look upon as another unsuccessful attempt at regional cooperation.

\footnotetext{
${ }^{84}$ Kubicek, End of the Line.

${ }^{85}$ National Democratic Party's Central Council, Asliddin Boliyev, 'Uzbek, Party Leaders Slam Eurasian Economic Community', at [http://www.uznews.com/news/10-26_00/uzb_par.html], 11 March 2001.
} 


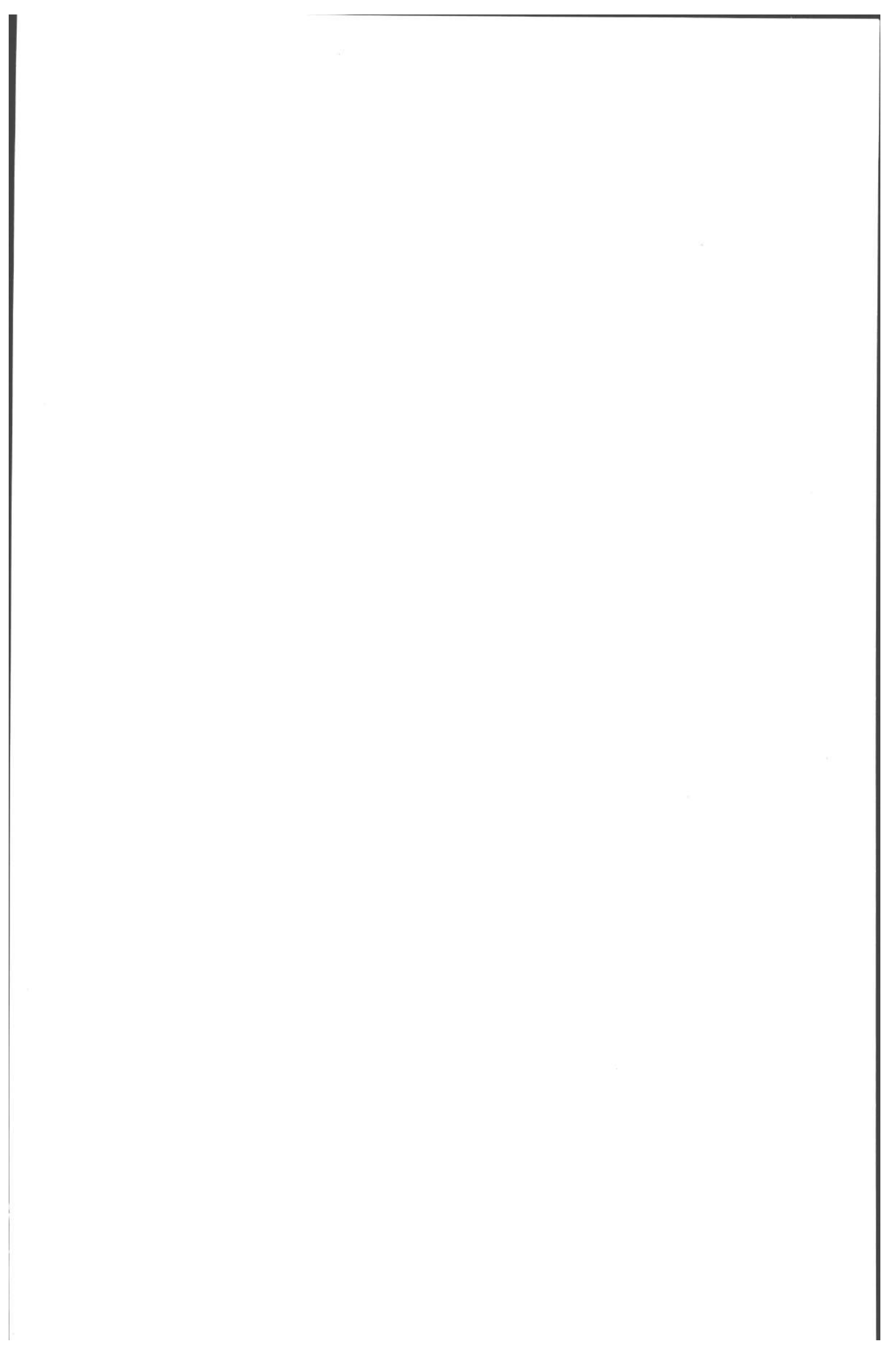




\title{
AN ANALYSIS OF THE WESTERN SCHOLARLY DISCOURSE ON TURKIC IDENTITY IN CENTRAL ASIA
}

\author{
HAYRIYYE KAHVECI
}

\begin{abstract}
The research question is formulated for this study as: Did Western scholarly discourse published in the period between 1950s and 1990s on Turkic identity in Central Asia reflect the Cold War political environment? When there is a rivalry between two states or two groups of states, it can be argued that the study of the other side tends to be biased and created to legitimate the sustainment of the rivalry. When we look at the Cold War political environment, which marked division of international relations into two political poles (East and the West), it is possible to observe this sort of a behavior between those parties as well. This paper relates to this tendency for ideology to affect knowledge. To examine this, the article focuses on the study of Turkic identity in Central Asia by the Western scholars.
\end{abstract}

\section{KEYWORDS}

Discourse; Orientalism; Turkic Identity; Central Asia; Basmac1 Movement; Jadid Movement; Turkic Muslim Congress. 